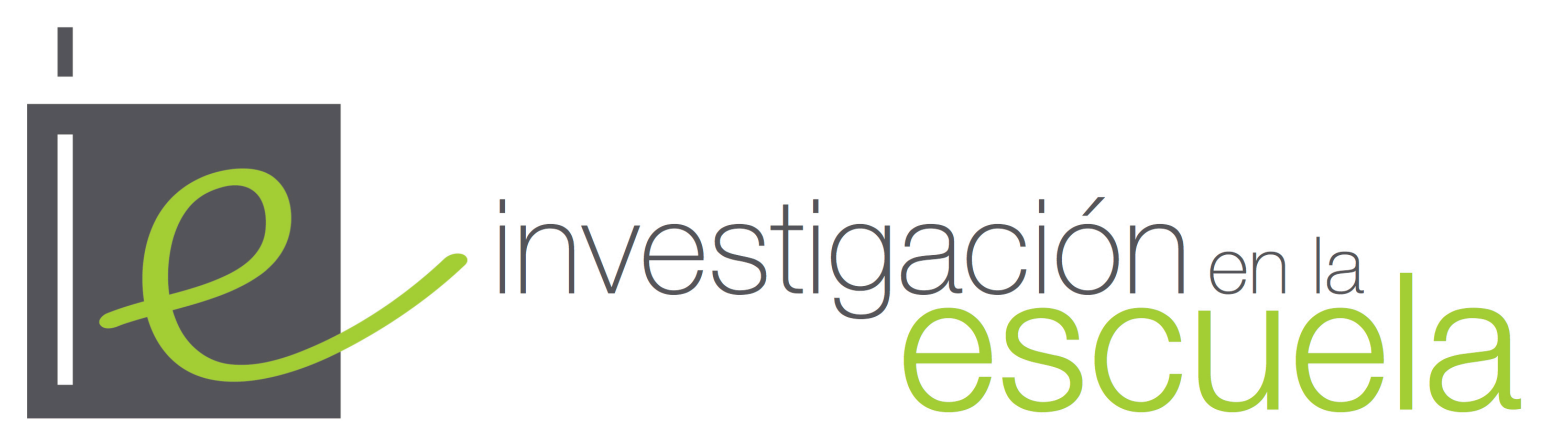

Revista internacional de investigación e innovación educativa

\title{
The biliteracy process in Primary Education: teachers and parents' perceptions on the use of phonic methods to develop emergent biliteracy skills
}

\author{
Sara Isabel Rendón-Romero, Macarena Navarro-Pablo y Eduardo García-Jiménez \\ Universidad de Sevilla \\ España
}

Citación: Rendón-Romero, S.I., Navarro-Pablo, M. y García-Jiménez, E. (2019). The biliteracy process in Primary Education: teachers and parents' perceptions on the use of phonic methods to develop emergent biliteracy skills. Investigación en la Escuela, 99, 31-45. doi:

http://dx.doi.org/10.12795/IE.2019.i99.03

Abstract: The type of method used inside the classroom to work on biliteracy skills can influence children's development and their motivation to acquire two different languages. This study aims to explore teachers and parents' perceptions on the implementation of phonic methods for the emergent biliteracy learning of 6 -year-old children; and to determine differences between the families' perceptions of private and state schools. This research counted with the pupils, their families and teachers from two schools from Seville, and was carried out through a nonexperimental research design, with a descriptive and cross-sectional nature. Data was collected through semi-structured interviews to teachers, analysed through a categorial system; and parents' questionnaires, analysed through a descriptive statistics and the Chi square test. Results present that teachers and families agree on the beneficial use of a phonic method to develop emergent English literacy skills and on children's positive learning regarding phonological awareness, vocabulary and, 
more especially, considering word and sentence reading. This study presents important implications regarding parents' raise of their awareness on the use of a method to offer a significant support at home.

Key words: "Literacy"; "Primary education"; "parents"; "teachers"; "literacy methods"; "transference, skills"; "English".

El proceso de alfabetización bilingüe en Educación Primaria: las percepciones de padres y profesorado sobre el uso de métodos fónicos para desarrollar habilidades de alfabetización emergente bilingüe

Resumen: El tipo de método usado en clase para el desarrollo de la alfabetización bilingüe puede influenciar en el desarrollo de cada niño y en su motivación por la adquisición de dos lenguas. Este estudio tiene por objetivo conocer las percepciones del profesorado y familias sobre el uso de métodos fónicos para el desarrollo de la alfabetización bilingüe de niños de 6 años. Además, pretende conocer las diferencias de opiniones de las familias de centros públicos y privados. Esta investigación contó con el alumnado, las familias y el profesorado de dos centros de Sevilla y se realizó bajo un diseño no experimental con naturaleza descriptiva y transversal. Se recogieron datos a través de entrevistas semiestructuradas al profesorado, analizadas siguiendo un sistema de categorías; y de cuestionarios a las familias, analizados a través un análisis descriptivo y de Chi cuadrado. Los resultados muestran que el profesorado y las familias están de acuerdo en que el uso de un método fónico para el desarrollo de habilidades de alfabetización en inglés es beneficioso y reconocen el aprendizaje positivo de los niños en relación a una mejora de la conciencia fonológica y vocabulario y, especialmente, en la lectura de palabras y frases en inglés. Este estudio presenta importantes implicaciones sobre la conciencia de los padres sobre el uso de un método para el apoyo significativo en el hogar.

Palabras clave: "Alfabetización"; "Enseñanza primaria"; "padres"; "profesorado"; "métodos de alfabetización"; "transferencia"; "competencia"; "inglés".

Les processus d'alphabétisation bilingue dans l'enseignement primaire: perceptions des enseignants et des parents sur l'utilisation des méthodes phoniques pour développer les compétences émergentes en alphabétisation bilingue

Resumè: Le type de méthode utilisé en classe pour le développement de l'alphabétisation bilingue peut influer sur le développement de chaque enfant et sur sa motivation pour l'acquisition de deux langues. Cette étude a pour objectif de connaitre les perceptions des enseignants et des familles sur l'utilisation de méthodes phoniques pour le développement de l'alphabétisation bilingue des enfants de 6 ans. En outre, il tente de connaitre les différences d'opinions des familles des centres publics et privés. Cette recherche a réuni les étudiants, les familles et les enseignants de deux centres à Séville et a été réalisée selon un plan non expérimental à caractère descriptif et transversal. Les données ont été collectées à travers des entretiens semi-structurés avec des enseignants, analysés à travers un système de catégories; et des questionnaires aux familles, analysés à l'aide d'une analyse descriptive et d'une analyse du chi carré. Les résultats montrent que les enseignants et les familles s'accordent pour dire que l'utilisation d'une méthode phonique pour le développement des compétences en alphabétisation en anglais est bénéfique et reconnaissent l'apprentissage positif des enfants en relation avec l'amélioration de la conscience phonologique et du vocabulaire, et surtout dans la lecture de mots et de phrases en anglais. Cette étude a des implications importantes pour la sensibilisation des parents à l'utilisation d'une méthode pour un soutien significatif à la maison. Mots-clés: "Alphabétisation"; "Enseignement primaire"; "parent"; "enseignant"; "méthode d'alphabétisation"; "transfert”; "competence"; "anglais". 


\section{The development of biliteracy skills through phonic methods}

The development of emergent literacy skills is related to the type of instruction performed in classrooms (Márquez, 2013; Pinto, Bigozzi, Vezzani, \& Tarchi, 2016). Throughout time, several studies have presented the use of two different teaching approaches for reading. As Guzmán-Simón Navarro-Pablo \& García-Jiménez (2015) describe, there are two specific approaches: synthetic and analytic. The former is based on a bottom-up teaching which starts with the smallest units of languages (phonemes, graphemes and syllables) to the widest or global units (words, sentences and texts). Through this approach pupils need to manage the decoding elements in order to be able to synthesise and blend so that they can later read properly. The phonic method is an example of this approach. Regarding the analytic approach, teaching is based on a top-bottom process, that it is, it starts with the global units and moves on to the smallest units of languages. Within this approach, the whole language or the language experience methods are used.

There is a constant debate focused on which type of method is best in order to teach how to read in English as a first and as a second language. Jiménez \& Artiles (2001) analyse both synthetic and analytic methods and concluded that both types of methods could present advantages for the learning development of the language. According to them, synthetic methods help pupils to memorize the phonological system faster and analytic methods present a more 'natural' learning process promoting children's interest and creativity. So, both methods have been source of analyses for many years. There has been different studies carried out in the U.S.A. and the United Kingdom regarding the methods used for teaching reading. After several reports on reading instruction throughout the history, the U.S.A National Reading Panel published a report in 1997, which concluded that teaching programmes which explicitly teach phonics were more effective than nonexplicit phonic programmes and the teaching focus should also be on fluency, vocabulary and reading comprehension. It is in the 1980s when phonics started to be used explicitly in the schools to teach how to read in English as a first language. Nowadays, it can clearly be seen in the Primary Framework for literacy and mathematics (2006). Although huge criticisms have been presented around the world on phonics (Campbell, Torr \& Cologon, 2011; Hannon, 1995; Hannon, 2001), several recent research studies also show that phonic methods can work regarding gender or any special need children may have and when English is taught as first or second language, presenting very good results regarding the reading development of children (Jolliffe \& Waugh, 2015; Nasrawi \& Al-Jamal, 2017; Savage, Georgiou, Parrila \& Maiorino, 2018). As a result, many programmes appeared focusing on phonics, as Jolly Phonics (Lloyd \& Wernham, 1998), which is the method used in the context of the present research.

As mentioned in Rendón-Romero, García-Jiménez, Navarro-Pablo (2019), methods for teaching how to read in Spanish should also be considered. The study concluded that the use of a phonic method combined with a global method seems to be more effective in order to teach how to read in Spanish. Several authors (Cuetos, 2008; Jiménez \& Ortiz, 2007) also mention the positive effects of using a phonic method to teach an alphabetic language as Spanish is. In the case of Spain, Micho, a phonic method has been used for a long time and it is still being used in many schools to teach how to read in Spanish with good results.

During the biliteracy learning process, pupils can develop emergent biliteracy skills which can be transferred in a bidirectional way and they can also acquire cognate words between languages (Reyes, 2006; Unsworth, Persson, Prins \& De Bot, 2015). Through a study carried out by RendónRomero, Navarro-Pablo \& García-Jiménez (2018), which was presented in an International Conference about Bilingual Education, focused on an experimental research design carried out with a phonic method during the first year of Primary Education in which 6-7-year-old Spanish children 
were learning how to read in English and Spanish at the same time. It is possible to see that teaching phonics in Spanish and English had positive results in pupils. More especifically, pupils in the experimental group of the study developed a higher phonological awareness and vocabulary than the control group. In addition, it seems that correlations exist between reading skills in Spanish and English which shows a positive transference among languages. Thus, using phonics to teach Spanish and English does not cause interference. On the other hand, it is helpful to foster a positive transference between the two languages.

The phonic method has also presented good results considering other aspects, such as motivation (Lorenzo, Casal \& Moore, 2009), which is an important part of children's social development. Young learners normally have more positive attitudes towards learning a language which can be crucial for their subsequent learning process. Positive motivation during lessons is highly significant and can help detect possible problems during the teaching-learning process. As Eshiet (2014) mentions children participate more actively during lessons and pay more attention. Farokhbakht (2015) also evinces that the experimental group using the phonic method were highly motivated in comparison to the control group, which was taught through a non-phonic method. Phonics also presents materials which seem quite adequate not only for the teaching-learning process but also to work on motivation as it is very visual and present fun activities. Through daily observations, pupils seem to be more enthusiastic and motivated during the lessons and teachers tend to feel more confident throughout the whole implementation (Eshiet, 2014). Teachers state that they use phonics programmes for pragmatic or personal reasons are related to children's interests and enjoyment and their own preferences (Campbell, Torr \& Cologon, 2011). Furthermore, teachers teach with more concentration and passion creating a participating classroom environment and keeping children engaged (Eshiet, 2014). In addition, López-Cirugeda \& López-Campillo (2016) mention that this method can motivate students when they have to read a text in English in subsequent years, being able to face the educational processes of bilingualism. Thus, in conclusion, the use of a phonic method seems to contribute to having a high motivation during the early literacy process.

Some case studies mention that several teachers found reading problems in their pupils. So, they were encouraged to use a phonic method. Although they were not too convinced at the beginning of the implementation, over the course of the year, their opinions about the use of the phonic method changed at the time that the implementation moves forward (Steele, s.f.; Robertson, s.f.). The case of Smith (s.f.), a teacher from St. Michael School, Bristol, decided to teach a phonic method after observing some reading problems in his pupils. Only three months later he could notice that these pupils significantly improved their literacy skills. Similar to this is the case of Wainwright (s.f.) (Reading and Special Needs Teacher) who says that her pupils' reading age was six months ahead of their actual age. Then, as it can be noticed, once the implementation of the phonic method finishes, teachers and parents finally appreciate the method's effectiveness.

Furthermore, Ekpo, Udosen, Afangideh, Ekukinam, \& Ikorok (2010) say that the phonic method can enhance the problems or impediments which cause children not to develop reading skills properly. Among these problems, they mention that the use of English in Primary Education, the high costs of books, inadequate instructional time, the poor preparation of teachers and the poor teaching methods, among others, are the principal causes of impeding children to develop reading skills. In relation to that, Moodie-Reid (2016) says that teachers' general opinions of this method refer to a positive effect on pupils with reading problems from the first to the third year of Primary Education.

To sum up, phonics can make children and teachers be more motivated with the provision of a synthetic method which uses proper and visual material. However, teacher training is still something which has to be covered in the different schools, specially, regarding the use of phonic 
methods for teaching English as a second language. It is also important to consider that parents' training in order to promote collaboration with the school as it has been considered to be beneficial for a better development of biliteracy skills (Beecher \& Makin, 2002; Jolliffe \& Waugh, 2015; Theodotou, 2017; Wright \& Peltier, 2016).

Regarding what literature says, it would be desirable to identify if the good results which are perceived by parents and teachers at the end of the implementation of a phonic method are also true in a Spanish context.

\section{Objectives}

The main objectives of this study are:

1. To explore teachers and parents' perceptions on the implementation of phonic methods for the emergent biliteracy learning.

2. To determine differences between the families' perceptions of private and state schools.

\section{Method}

This study followed a non-experimental research design, with a descriptive and crosssectional nature (Martínez Arias, Castellanos López \& Chacón Gómez, 2014). This research counted with the participation of two bilingual schools with different characteristics. One of them (School 1), a public school, is situated in a neighbourhood near the centre of the city. It presented an early immersion bilingual programme and teachers were receptive to use new methodologies to improve their bilingual teaching programme. In addition, this school had not have used phonic methods before. The other (School 2), a private school, is situated in the historical centre. It had been using phonics for some years and were receptive to know how their students were improving along the years by using phonics for teaching the first and second language. The total sample was composed of 3 teachers, 142 pupils and their corresponding families.

The reason why these two schools were chosen was related to the main problem detected that is based on how to face literacy in a second language (English in this case), which is being introduced in earlier years in Spain. So, these two schools were chosen due to the differences regarding this problem as School 1 did not have used any method for teaching how to read in English while School 2 had had experience in using methods for teaching literacy in the early years. They were also chosen due to the fact that it was important to know parents' perceptions on a literacy method which was something new for them in the case of the School 1.

These differences among schools allowed the researchers to carry out an intervention in School 1 and observations in School 2 as an intervention control, that is, as a reference. In School 1, teachers were using a non-phonic method focused on the learning of vocabulary through semantic fields but with no focus on phonics. Due to that, the research could perform an intervention with a phonic method in one group while the control group continued learning through the non-phonic method already mentioned. Pupils from School 1 had no knowledge of English phonics and were not able to read and understand any spoken text. For this reason, a phonic method was decided to be used in order to improve emergent literacy skills in English. This method focused on the teaching of 42 letter sounds which are linked to an action. Children connect the sound to the symbol of the letter and work on vocabulary and comprehension through stories, flashcards, songs and different type of activities and games. The focus of the method is to work on learning the letter sounds and 
letter formation, blending sounds into words, identifying sounds in words, and working with difficult or tricky words which do not follow any phonetic pattern.

The transition from a non-phonic method to a phonic method in School 1 was confusing for some of the pupils as they were learning different aspects of the language. In addition, parents did not know how to help them at home. However, with time, they got used to it and with practice children developed their literacy skills in English and parents participated more helping them with activities at home, which were suggested by the teacher. So, parents' engagement was very important. They were demanded to carry out some activities related to the method at home to reinforce the knowledge learnt at school.

Once schools accepted to participate, teachers and parents signed the consent, and observations were possible to carry out as well as the intervention with an English phonic method in School 1. According to the Spanish curriculum, phonics is part of the language teaching in the early years. However, it is not presented as the focus of the teaching during the Primary Education period.

Data were collected through semi-structured interviews, which were based on the seven questions used by Eshiet (2016) in this author's research as they were considered for the same purpose. In this case, one Spanish teacher of English was interviewed in the state school. This teacher was young and very receptive to know new methodologies. According to her, she had never used phonics before due to the lack of teacher training. In the case of the private school, two English teachers of English were interviewed. Both of them were native English speakers. They had been using phonics in England and they had been using it in School 2 for two years. The interview included questions related to the impact of the phonic method to teach how to read in English and the strong and weak points of the method.

Regarding parents, they received a questionnaire, whose questions, taken from Eshiet (2016, pp. 22-23) in a pilot project in Winneba, Ghana, were related to children's final objectives attained by pupils according to parents and their opinion of the phonic method. The reliability of the test was Cronbach's alpha $=0.84$.

Data from interviews were analysed through a categorial system organised in two different macro categories: consequences on learning and consequences on students' motivation. On the one hand, the category consequences on learning consisted of five categories: teacher learning, students' phonological awareness, students' vocabulary, support to students to learning difficulties and critical events during learning process. On the other hand, consequences on students' motivation consisted of three categories enthusiasm, attention and participation.

Through this system, the information collected were coded. After that, the information was interpreted conceptually from the previous identified categories. In the case of the questionnaire, it was analysed through descriptive statistics and the Chi square test with a final sample of 115 parents.

\section{Results}

Results will be presented first regarding teachers' perceptions on the use of a phonic method in each school and will continue with parents' perceptions and the differences found between schools regarding their opinions.

\section{Teachers' perceptions on the use of an English phonic method}

With regard to the analysis of the interviews, there were three important categories which helped to understand the teachers' opinions of the phonic method used during the first year of Primary Education of Spanish children learning how to read in English: learning, motivation and 
transference of reading skills. This analysis concludes with the strengths and weaknesses of using a phonic method according to the teachers' view.

The first category was related to "learning". Within this category sub-patterns were created which were related to teacher's learning, pupils' learning of phonological awareness, pupil's learning of vocabulary, helping struggling readers and important moments of the learning process. Regarding teacher's learning, it is important to clarify that the initial situation of each school was different due to the fact that in School 1 teachers had no previous experience with an English phonic method while teachers from School 2 had been using phonics for some years. This is the reason why the teacher from School 1 said that being part of this research was an opportunity for her to learn new methodologies in order to improve the education of her pupils.

Regarding children's learning, the teacher from School 1 also emphasized it as one of the most important aspect of the method. She said that her pupils had learnt how to read in English with no previous knowledge of English reading skills. She said her pupils started to read words and some of them were even reading full sentences. She also mentioned that the children learnt to develop their phonological awareness and vocabulary in an easy, rapid and ludic way with no much effort in the learning process. She says that they learnt through games, songs and stories and then, they realized they were learning, which gave them satisfaction about their learning achievement. It was an aspect also mentioned by the teachers in School 2. They commented that it is very motivating for teachers when their pupils don't really realize they are learning because they are having fun.

The increase of vocabulary learning was possible thanks to the recycling characteristic of the phonic method. The teacher from School 1 said that vocabulary was not presented around a specific topic but all vocabulary was repeated in all sessions. This favored children's better acquisition. However, she mentioned that the non-phonic method which she was using in the control group focused on learning vocabulary through lists of words of the same semantic field and on the learning of grammatical structures. She says this method was not so successful since children did not retain vocabulary and were not able to read anything. This was due to the fact that the non-phonic method was not doing an appropriate recycling.

In the case of the teachers from School 2, apart from referring to the 'learning' through phonological awareness acquisition, one of them mentioned that it is a method which could also help struggling readers. They also commented that the phonic method helps teachers and pupils because it is very systematic. In this way, according to them, teachers have the whole planning prepared beforehand thanks to the systematicity of the phonic method used.

In addition, 'learning' was related to the fact that the teacher from School 1 related it to the most important moment during the implementation of the phonic method, which she referred to as the first time that a student read a whole sentence in English with no problem. In fact, the teacher from School 1 could not believe what her pupils had achieved, she even stated that it was amazing how children who did not know reading in English at all started to read full sentences in English with a correct pronunciation.

The second category was related to 'motivation', in which three sub-patterns were found: attention, enthusiasm and participation. The teacher from School 1 commented that her pupils did not reduce their motivation in the whole year. They always wanted to participate and paid a lot of attention. She mentioned that pupils were always eager for learning more. This commentary coincided with the one that teachers in School 2 mentioned, who was based on the fact that the most important thing for them is enthusiasm because they consider that if children feel enthusiastic and motivated, they learn.

The third category was related to the transference of reading strategies in the teachinglearning process. The teacher from School 1 said that the literacy skills learnt in one language can be 
transferred to the other language. She also mentioned that she was trying to use some ideas to introduce phonics in the Spanish lesson. However, in the School 2, the teachers warned that although transference happens among reading skills in the two languages and some sounds do not need much work because they are the same in Spanish, they have to be careful so as not to mix English with Spanish because children could be confused.

All these three ideas presented above could be summed up as the strengths of the English phonic method, which includes positive view regarding the learning of a new method to teach reading skills, successful pupils development of phonological awareness and the increase of vocabulary, high motivation and the existence of transference of reading skills between languages. As a conclusion, the teacher from School 1 emphasized the positive aspects of the phonic method and her intention to continue using it. Teachers in School 2, when asked if they would continue using the method, they answered: 'Definitely yes' (Interview, teacher 1 and 2. School 2, 4th June 2018).

Finally, as the weaknesses of the method, the teacher from School 1 mentioned possible improvements of the method in order to be used in the following years of Primary Education. Specifically, she said that the method, as being designed by and for English speakers to be used in an English context, it did not include much about communicative skills. So, this is something which she considered necessary to be included if this method is used in a Spanish school where English is only used inside classrooms.

In the case of teachers from School 2, they mentioned that the method also needed to be adapted as it was being used in Spain with 6-7-year-old children and there were some things which were too childish for them considering that the method is designed for 5-year-old English children: "the one thing I would say in the negative side is that the yellow books have a lot of colouring in them and can be tedious for this age group because, generally, the Jolly Phonics' in other countries would start earlier and so, we decided that not specially to colour that much and write more sentences or words with the sounds that we are working. So, you have to adapt a bit". (Interview, teacher 2, School 2, 4th June 2018).

\section{Parents' perceptions on the use of an English phonic method}

As parents were asked to carry out some activities related to the phonic method at home to reinforce the knowledge learnt at school, they could observe the development of their children in a daily basis. Due to that, parents knew about the phonic method, the elements they needed to work and the type of activities they could perform. Thus, they were able to answer the questionnaire provided by the researchers with significant information.

Then, regarding parents' perceptions on children's achievement, through the descriptive analysis, it could be seen that most of them agreed o that their children were able to recognise individual sounds and actions $(\mathrm{n}=90)$; to read words in English $(\mathrm{n}=93)$; to read short sentences in English ( $n=74)$; singing songs of the method $(n=89)$; and they were motivated with stickers at classroom ( $n=75)$. Finally, they agreed on the fact that the method was good for the development of English ( $\mathrm{n}=90)$. Only one disagreed, another one was not sure and 23 did not answer the question (Figure 1). 


\section{Is phonics good to develop English literacy skills?}

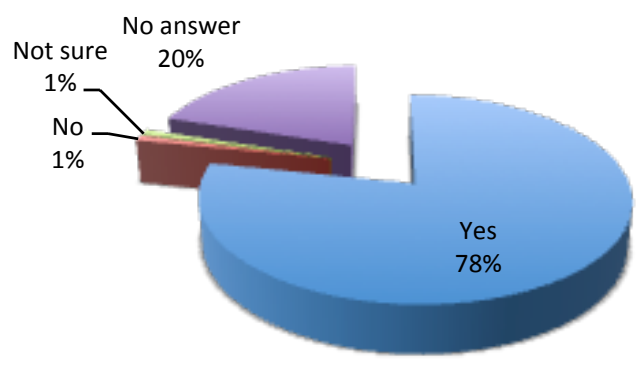

Figure 1. Parents' opinions of using a phonic method to develop emergent English literacy skills

If the attributions of parents from the two schools about their children achievement are compared, statistically significant differences can be found in reading words and sentences in English in favour of School 2 (¡Error! No se encuentra el origen de la referencia.). Parents from School 2 affirm that their children are able to read words and sentences in English, showing a higher percentage than parents from School 1.

Table 1

Comparisons of parents' attributions of children's achievement

In your opinion, is your child able to recognise individual sounds in English (indicating the sound and the action)?

In your opinion, is your child able to read words in English?

.033 School 2

In your opinion, is your child able to read sentences in English? .001 School 2

In your opinion, is your child able to sing songs in English? $\quad .144$

In your opinion, is your child motivated when receiving a sticker

in the English lesson?

In your opinion, is phonics a good method to develop English? $\quad .697$

\section{Summary of results}

The following Table 2 is presented in order to synthesize the results found from teachers' interviews and parents' questionnaire. Teachers and parents positively value the use of an English phonic method to develop emergent literacy skills although some elements could be adapted. 
Table 2

Synthesis of results

\begin{tabular}{|c|c|c|}
\hline & The method is good for... & However... \\
\hline $\begin{array}{l}\text { Teachers' opinions (School } \\
1 \text { and } 2 \text { ) }\end{array}$ & $\begin{array}{l}\text {...teacher's learning of new } \\
\text { methodologies, pupils' learning } \\
\text { of phonological awareness and } \\
\text { vocabulary, having high } \\
\text { motivation inside the } \\
\text { classroom and the transference } \\
\text { of reading strategies among } \\
\text { languages. }\end{array}$ & $\begin{array}{l}\text { The method needs some } \\
\text { adaptations for Spanish } \\
\text { pupils of } 6 \text { years old. }\end{array}$ \\
\hline Parents' opinions & $\begin{array}{l}\text {...children as they can read } \\
\text { words, sentences, sing songs } \\
\text { and are motivated inside the } \\
\text { classroom. (School } 1 \text { and } 2 \text { ) } \\
\text {...the development of English } \\
\text { literacy skills. (School } 1 \text { and } 2 \text { ) }\end{array}$ & $\begin{array}{l}\text { Parents from School } 2 \\
\text { attributed a higher } \\
\text { percentage to the fact that } \\
\text { their children were able to } \\
\text { read words and sentences in } \\
\text { English. }\end{array}$ \\
\hline
\end{tabular}

\section{Discussion and conclusions}

The use of phonic methods to develop emergent biliteracy skills is considered to be appropriate according to teachers' and parents' view. This supports what other authors mention related to the good results of using a phonic method in the development of literacy in the early years (Cuetos, 2008; Jiménez \& Ortiz, 2007; Jolliffe \& Waugh, 2015; Nasrawi \& Al-Jamal, 2017; Savage et al., 2018; Rendón-Romero, García-Jiménez, Navarro-Pablo, 2019). Parents and teachers believe that learning to read and write in two different languages during the Primary Education period is beneficial.

The first objective of this study is based on teachers perceptions on the implementation of phonic methods for the emergent biliteracy learning. Through teachers' interviews it is possible to identify some aspects which they considered to be important during the implementation of the phonic method, which are teachers' training, pupils' learning and motivation, and transference of literacy skills between the two languages.

Teachers agree on the fact that this research was useful for them to learn a new method to teach how to read in English. This is related to the responses that Eshiet (2016) received by different teachers as most of them agreed to have joined the research to improve and be exposed to this type of phonic method. Teachers in the present research also mention this method is good for children's development of phonological awareness and vocabulary and for those children who present reading problems, similar to the responses of the teachers interviewed by Moodie-Reid (2016), who reported good results for struggling readers.

In addition, teachers emphasise important moments when some children read in English for the first time or identified some sounds in spoken words. All teachers agree that motivation, attention, enthusiasm and participation were the most important aspects they found in children's learning with a phonic method as they were always eager to participate in every lesson and learn more. The responses received by Eshiet (2016) are similar to these. Teachers agree that the phonic 
method helps pupils 'easily identify sounds' and they 'are eager to learn more' (pp. 27-28). They also say that pupils learn in such a fun way that they do not even realise they are learning.

Regarding transference, Cummins (2001) mentions that pupils can use and apply the literacy skills acquired in their first language in order to develop these skills in the second language. In this research, teachers also mention that their English reading skills can be transferred to their mother tongue as they noticed children were using English reading strategies to learn some letter sounds in Spanish and vice versa. This confirms what Reyes (2006) mentions about the fact that transference can be bidirectional. However, other teachers consider that this aspect should be taken with care as not to confuse them with the phonological system of each language. This idea, however, is not found by teachers interviewed by Eshiet (2016) as the present research seems to be the first one considering the use of an English phonic method in Spain. One of the teachers interviewed by this author even suggest that the phonic method could be a good option to teach English literacy in contexts where English is not the first language.

The first objective also considers parents' perceptions on the implementation of phonic methods for the emergent biliteracy learning. They consider their children were able to identify individual sounds and blend them to pronounce complete simple and complex words and even sentences. They also mention children felt motivated inside the classroom through different strategies, which is aligned to what Lorenzo et al. (2009), Farokhbakht (2015) and López-Cirugeda \& López-Campillo (2016) mention regarding the fact that a phonic method can raise children's motivation inside the classroom. As a conclusion of parents' opinions regarding the use of a phonic method, almost all of them consider it to be good for the development of English, as they could probably see that their children were improving. Thus, similar to what Eshiet (2016), Steele (s.f.), Robertson (s.f.) and Wainwright (s.f.) mention, not only teachers' but also parents' perceptions change at the end of the implementation of a phonic method.

Considering the second objective of this work, it is focused on determining the differences between schools considering the families' perceptions on their children's achievements. Through the questionnaires, it is possible to see that School 2 presented a higher percentage regarding children's ability to read words and sentences in English. This may be due to the fact that children from School 2 had been learning English phonics before the Primary Education period. This is the reason why their level of English was higher as they were reading through a lexical route. This is aligned to what Coltheart (1985); Cuetos (2008), Rendón-Romero, García-Jiménez, Navarro-Pablo (2019) mention about the lexical route.

In conclusion, it is possible to say that teachers and parents perceive that the use of a phonic method is beneficial to develop emergent English literacy skills in a Spanish school context as they could see the positive results that it had on their children. Among these positive results, teachers highlight the development of phonological awareness and vocabulary, the transference of literacy skills between two languages and the high motivation perceived in every lesson of the implementation. Parents add that their pupils can read words and sentences in English, which is a relevant result of the phonic method. However, it is possible to agree with Beecher \& Makin (2002), Jolliffe \& Waugh (2015), Wright \& Peltier (2016) and Theodotou (2017) on the fact that training seems to be important not only for teachers but also for parents in order to understand phonic methods and know how they can collaborate with the school to actively participate in pupils' development of the biliteracy process. Finally, it is important to mention that this study presents important implications regarding parents' raise of their awareness on the use of a phonic method to offer a significant support at home. 


\section{Referencias}

Beecher, B., \& Makin, L. (2002). Languages and literacies in early Childhood: At home and in early childhood settings. European Early Childhood Education Research Journal, 10(1), 67-84. doi: $10.1080 / 13502930285208851$

Campbell, S., Torr, J. \& Cologon, K. (2011). Ants, apples and the ABCs: The use of commercial phonics programmes in prior-to school children's services. Journal of Early Childhood Literacy 12,(4), 367-388. doi: 10.1177/1468798411417377

Coltheart, M. (1985). Cognitive neuropsychology and the study of Reading. In M. Posner \& G. Marin (Eds.). Attention and performance XL. Hillsdale: LEA.

Cuetos, F. (2008). Psicología de la lectura. Madrid, España: Wolters Kluwer Educación.

Cummins, J. (2001). Language, Power and Pedagogy: Bilingual children in the crossfire. Clevedon, United Kingdom: Multilingual Matters.

Ekpo, M., Udosen, A. E., Afangideh, M. E., Ekukinam, T. U. \& Ikorok, M. M. (2010). Jolly Phonics strategy and the ESL pupils' reading development: a preliminary study. Mid-term Conference. University of Ibadan, Ibadan, Oyo State, United Stated of America. Recovered on March, 12th 2018 from http://jollylearning.co.uk/2011/03/24/research/

Eshiet, O. I. (2016). Intervention for struggling readers. United Kingdom: Optimalpath Consulting Limited. Farokhbakht, L. (2015). The Effect of Using Multisensory-based Phonics in Teaching Literacy on EFL Young Female/Male Learners' Early Reading Motivation: A Case of Iranian Young Learners of English. (PhD). University of Isfahan, Iran. Recovered on March, 12th 2018 from http://jollylearning.co.uk/2011/03/24/research/

Guzmán-Simón, F. Navarro-Pablo, M. y García-Jiménez, E. (2015). Escritura y lectura en Educación Infantil. Conceptos, secuencias didácticas y evaluación. Manual. Madrid: Ediciones Pirámides.

Hannon, P. (1995). Literacy, Home and School: Research and Practice in Teaching Literacy with Parents. London, United Kingdom: RoutlegeFalmer.

Hannon, P. (2001). Reflecting on Literacy in Education. London, United Kingdom: Taylor \& Francis eLibrary.

Jiménez, J. E. \& Artiles, C. (2001). Cómo preveniry corregir las dificultades en el aprendizaje de la lectoescritura. Madrid: Síntesis.

Jiménez, J. E. \& Ortiz, M.R. (2007). Conciencia Fonológica y aprendizaje de la lectura: Teoría, evaluación e intervención. Madrid: Síntesis.

Jolliffe, W. \& Waugh, D. (2015). Teaching Systematic Synthetic Phonics in Primary Schools. London, United Kingdom: Learning Matters.

López-Cirugeda, I. y López-Campillo, R. M. (2016). El método sistemático-sintético de lectoescritura Phonics como herramienta para la adquisición de la fonética inglesa. Revista Fuentes, 18(2), 183195. doi: http://dx.doi.org/10.12795/revistafuentes.2016.18.2.05

Lorenzo, F., Casal, S. \& Moore, P. (2009). The effects of content and language integrated learning in European education: Key findings from the Andalusian bilingual sections evaluation project. Applied Linguistics, 31(3), 418-442. doi: 10.1093/applin/amp041

Lloyd, S. \& Wernham, S. (1998). The Phonics Handbook. A handbook for teaching Reading, Writing and Spelling; in print letters. (3rd edition). Essex, United Kingdom: Jolly Learning.

Márquez, M. (2013). Estrategias utilizadas en aulas bilingües en la enseñanza de la lectura en español. (PhD). University of Texas-Pan American, United States of America. Recovered on January, $10^{\text {th }} 2017$ from http://0-search.proquest.com.fama.us.es/index. 
Martínez Arias, R., Castellanos López, M. A. \& Chacón Gómez, J. C. (2014). Método de investigación en psicología. Madrid: EOS.

Moodie-Reid, L. (2016). Teachers" Perceptions of the Impact of the Jolly Phonics Program on Students" Literacy. (PhD). Walden University, Minneapolis, United States of America. Recovered on March, $10^{\text {th }}$ 2018 from de http://scholarworks.waldenu.edu/dissertations

Nasrawi, A. \& Al-Jamal, D. (2017). The effect of using jolly phonics on Jordanian first grade pupils' reading. International Online Journal of Education and Teaching (IOJET), 4,(2). 106-119. http://iojet.org/index.php/IOJET/article/view/172/155

National Reading Panel. (1997). Teaching Children to Read: An Evidence-based Assessment of the Scientific Research Literature on Reading and its Implications for Reading Instruction. Recovered from https://www.nichd.nih.gov/sites/default/files/publications/pubs/nrp/Documents/report. pdf

Pinto, G., Bigozzi, L., Vezzani, C., \& Tarchi, C. (2016). Emergent literacy and reading acquisition: a longitudinal study from kindergarten to primary school. European Journal of Psychology of Education, 1-17. doi: 10.1007/s10212-016-0314-9

Primary Framework for literacy and mathematics (2006). Department of Education. Primary National Strategy.

Savage, R., Georgiou, G., Parrila, R. \& Maiorino, K. (2018). Preventative Reading Interventions Teaching Direct Mapping of Graphemes in Texts and Set-for-Variability Aid At-Risk Learners. Scientific Studies of Reading, 22(3), 225-247. doi: 10.1080/10888438.2018.1427753

Rendón-Romero, S.I., Navarro-Pablo, M. y García-Jiménez, E. (2018). La alfabetización bilingüe en Educación Infantil y Educación Primaria: el método Jolly Phonics. En X. Gisbert (Presidencia). Comunicación llevada a cabo en el V Congreso Internacional de Enseñanza Bilingüe en Centros Educativos, Universidad de Salamanca (Extremadura).

Rendón-Romero, S.I., García-Jiménez, E. y Navarro-Pablo, E. (2019). La lectura de palabras: la influencia del procesamiento fonológico y del método lectoescritor. Revista Fuentes, 21(1), 11 24. doi: 10.12795/revistafuentes.2019.v21.i1.01

Reyes, I. (2006). Exploring connections between emergent biliteracy and bilingualism. Journal of Early Childhood Literacy, 6(3), 267-292. doi: 10.1177/1468798406069801

Robertson, L. (s.f.). Supporting staff through the changes. Jolly Learning Ltd. Recovered on March, $12^{\text {th }}$ 2018 from http://jollylearning.co.uk/2011/03/24/research/

Smith, P. (s.f.). And why are all these children pretending to click castanets? Jolly Learning Ltd. Recovered on March, $12^{\text {th }} 2018$ from http://jollylearning.co.uk/2011/03/24/research/

Steele, A. (s.f.). What made their teaching so special. Jolly Learning Ltd. Recovered on March, $12^{\text {th }} 2018$ from http://jollylearning.co.uk/2011/03/24/research/

Theodotou, E. (2017). Literacy as a social practice in the early years and the effects of the arts: a case study. International Journal of Early Years Education, 25(2), 143-155. doi: 10.1080/09669760.2017.1291332

Unsworth, S. Persson, T. P. \& De Bot, D. (2015). An Investigation of Factors Affecting Early Foreign Language Learning in the Netherlands. Applied Linguistics, 36(5), 527-548. doi: 10.1093/applin/amt052

Wainwright, T. (s.f.) Easier reading, easier writing. Jolly Learning Ltd. Recovered on March, $12^{\text {th }} 2018$ from http://jollylearning.co.uk/2011/03/24/research/

Wright, T. S. \& Peltier, M. R. (2016). Supports for Vocabulary Instruction in Early Language and Literacy Methods Textbooks. Reading and Writing Quarterly, 32(6), 527-549. doi: 10.1080/10573569.2015.1031925 


\section{Información sobre los autores}

Autora: Sara Isabel Rendón-Romero

Institución: Departamento de Didáctica de la Lengua y la Literatura y Filología Integradas. Universidad de Sevilla

Email: sararenrom@gmail.com

ORCID: http://orcid.org/0000-0002-1150-7822

Autora: Macarena Navarro-Pablo

Institución: Departamento de Didáctica de la Lengua y la Literatura y Filología Integradas.

Universidad de Sevilla

Email:mnp@us.es

ORCID: http://orcid.org/0000-0003-1954-0851

Autor: Eduardo García-Jiménez

Institución: Departamento de Métodos de Investigación y Diagnóstico en Educación. Universidad de Sevilla

Email: egarji@us.es

ORCID: http://orcid.org/0000-0002-5885-8267 


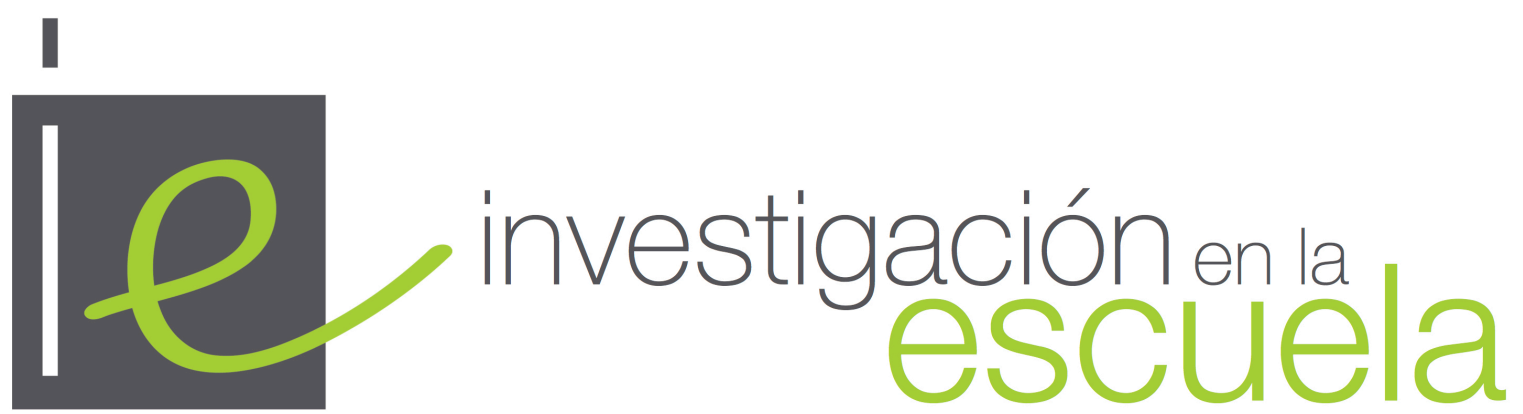

Revista académica evaluada por pares y de acceso abierto

Número 99

30 de diciembre de 2019

ISSN 2443-9991

\section{(c) (i) (2)}

Esta obra está bajo una licencia Creative Commons. Los/as lectores/as pueden compartir, copiar y redistribuir el material en cualquier medio o formato, así como adaptar, remezclar, transformar y construir a partir del material para cualquier propósito, incluso comercialmente. Para ello, deben de hacerlo bajo los siguientes términos: dando crédito de forma adecuada, brindando un enlace a la licencia e indicando si se han realizado cambios. Si se remezcla, transforma o crea a partir del material, debe distribuir su contribución bajo la misma licencia del original.

Más detalles de la licencia de CreativeCommons se encuentran en https://creativecommons.org/licenses/by-sa/4.0/deed.es

Cualquier otro uso debe ser aprobado en conjunto por el autor/es, o Investigación en la Escuela.

U.

Revista Editada por la Universidad de Sevilla. https://editorial.us.es/es/revistainvestigacion-en-la-escuela

Por errores y sugerencias contacte a secretaria@investigacionenlaescuela.es

La revista Investigación en la Escuela desde su origen en 1987 hasta su no 87 (2015) fue editada por Díada Editora. 
